\title{
Peach brown rot control and the relationship of latent infection with postharvest disease ${ }^{1}$
}

\author{
Elizandra Pivotto Pavanello ${ }^{2}$, Magno Roberto Pasquetti Berghett ${ }^{3}$, Erani Eliseu Schultz ${ }^{3}$, Fabio Rodrigo Thewes ${ }^{3}$, \\ Suele Fernanda Prediger Schmidt ${ }^{3}$, Auri Brackmann ${ }^{2}$
}

$10.1590 / 0034-737 X 201865060007$

\begin{abstract}
The peach brown rot, caused by Monilinia fructicola, is the main disease of the crop, causing significant losses during preharvest and postharvest. This study aimed to evaluate the performance of preharvest fungicide application on brown rot control and verify the role of latent infection and external contamination in postharvest disease. An experiment was carried out in the years 2014 and 2015 in order to evaluate the performance of six active ingredients (captan, iprodione, iminoctadine, tebuconazole, difenoconazole and azoxystrobin) during preharvest on brown rot control and the effect on latent infection. A second experiment was carried out to monitor the latent infection during growth and ripening of the fruit and in order to correlate it with the postharvest disease incidence. The data were submitted to analysis of variance (Anova) and the means were grouped by the Scott-Knott test ( $<<0.05$ ), using statistical software Sisvar. The active ingredients iprodione, tebuconazole and difenoconazole were the most efficient in controlling brown rot on the field, while iminoctadine has higher efficiency during postharvest control, acting on latent infections. The incidence of latent infections during fruit growth and ripening has a positive correlation with brown rot incidence at postharvest. The highest disease incidence after storage is due to the latent infections manifestation. Effective chemical control in the field, throughout the growing and ripening of fruit, is an important approach to postharvest brown rot control, even after cold storage and during shelf life at $20^{\circ} \mathrm{C}$.
\end{abstract}

Keywords: cold storage; fungicides; Monilinia fructicola.

\section{RESUMO}

\section{Controle da podridão parda do pessegueiro e a relação da infecção latente na doença em pós-colheita}

A podridão parda do pessegueiro, causada pelo fungo Monilinia fructicola, é a principal doença da cultura, causando danos significativos tanto em pré-colheita como pós-colheita. O estudo objetivou avaliar a aplicação précolheita de fungicidas, no controle da podridão parda e verificar o papel da infecção latente e contaminação externa na incidência da doença em pós-colheita. Foi conduzido um experimento nos anos de 2014 e 2015 para avaliar o desempenho de seis ingredientes ativos em pré-colheita (captana, iprodiona, iminoctadina, tebuconazol, difenoconazol e azoxistrobina) no controle da podridão parda e o efeito sobre infecções latentes. Um segundo experimento objetivou monitorar a infecção latente durante o crescimento e maturação dos frutos, correlacionando-a com a incidência da doença em pós-colheita. Os dados formam submetidos a análise de variância (Anova) e as médias agrupadas pelo teste de Scott-Knott $(\mathrm{p}<0,05)$ com o software estatístico Sisvar. Os produtos iprodione, tebuconazol e difenoconazol foram os mais eficientes no controle da podridão parda a campo, enquanto o iminoctadine possui maior eficiência em póscolheita, agindo inclusive sobre as infecções latentes. A incidência de infecções latentes tanto na fase de crescimento

Submetido em 02/04/2018 e aprovado em 27/11/2018.

${ }^{1}$ Este trabalho faz parte da tese do primeiro autor.

${ }^{2}$ Universidade Federal de Santa Maria, Departamento de Fitotecnia, Santa Maria, Rio Grande do Sul, Brasil. elizandra_pavanello@yahoo.com.br; auribrackmann@gmail.com ${ }^{3}$ Universidade Federal de Santa Maria, Santa Maria, Rio Grande do Sul, Brasil.magno.pasquetti@gmail.com; suele fernanda@hotmail.com; fthewes@yahoo.com; eranischultz@ hotmail.com *Corresponding author: magno.pasquetti@gmail.com 
quanto maturação tem correlação positiva com a podridão parda em pós-colheita. A maior incidência da doença após o armazenamento foi em decorrência da manifestação de infecções latentes. O eficiente controle químico no campo, durante toda a fase de crescimento e maturação dos frutos é uma importante estratégia para o controle pós-colheita, inclusive após o armazenamento refrigerado e durante a vida de prateleira sob $20^{\circ} \mathrm{C}$.

Palavras-chave: armazenamento refrigerado; fungicidas; Monilinia fructicola.

\section{INTRODUCTION}

The peach brown rot, caused by fungus Monilinia fructicola, is the main disease of the crop, causing significant losses in pre and postharvest. These losses resulted from infection of flowers and fruit, during harvest and postharvest (Larena et al., 2005; Villarino et al., 2012). The fruit susceptibility to $M$. fructicola increase at the final stages of fruit development, during the maturation phase, and over the postharvest (Luo \& Michailides, 2003; Villarino et al., 2011). Postharvest losses in peaches normally occur during transport and storage and may reach $80 \%$ (Sestari et al., 2008); even when performing the recommended prophylaxis measurements.

The control of the disease during postharvest is essential to reduce the inoculum in the field, preventing manifestation of the disease during fruit storage and marketing. Thereby, the chemical control with fungicide is the most efficient method, spraying the plants from flowering until the preharvest stages of fruit development (Holb \& Schnabel, 2007; May-De Mio et al., 2008; Moreira \& May-De Mio, 2009; Casals et al., 2012). Preharvest fungicide application is indispensable, especially for areas with high inoculum pressure, or in cases of damage caused by insects or hail during fructification (Luo et al., 2001). Fungicides, such as iminoctadine, iprodione (Moreira \& May De Mio, 2009; Pavanello et al., 2015), trifloxystrobin/ tebuconazole and difenoconazole (Pavanello et al., 2015), reduced the brown rot incidence more than $85 \%$ after cold storage. Burnett et al., (2010) observed that azoxystrobin and trifloxystrobin are able to reduce the sporulating areas by $60 \%$, presenting a high curative ability to fight infections caused by the fungus Monilinia fructicola.

Immature fruit usually show no visual symptoms of infection with $M$. fructicola, but can harbor asymptomatic infections (latent). Latent infections may become active when the fruit ripen, exacerbating the disease incidence in harvest and postharvest (Emery et al., 2000). These infections are more important in temperate and humid regions, where they can easily develop into rot, occurring throughout the growth period of the fruits and being positively correlated with the incidence of the disease at harvest and postharvest (Northover \& Cerkauskas, 1994;
Emery et al., 2000, Xu et al., 2007). Understanding the importance of latent infection of brown rot epidemiology could facilitate early detection of the risk of rot before harvest, influencing the decisions for the management of the disease. Furthermore, the efficient use of fungicides during the preharvest rot control is important to reduce peach loss, especially in postharvest, when the fruit is subject to injuries and more sensitive to latent infection. Thus, the aim of this study was to evaluate the performance of fungicides applied during preharvest on brown rot control of peach and to identify the role of latent infection and external contamination in the incidence of postharvest brown rot.

\section{MATERIALAND METHODS}

The study was carried over the course of years 2014 and 2015, in a commercial orchard of peach in the city of Santiago, Rio Grande do Sul state, Brazil, located at an altitude of $409 \mathrm{~m}, 29^{\circ} 11^{\prime} 30^{\prime \prime} \mathrm{S}$ and $54^{\circ} 52^{\prime} 02^{\prime \prime} \mathrm{W}$. The postharvest experiment was carried out in Santa Maria, Rio Grande do Sul state, Brazil located at ab altitude of $85 \mathrm{~m}$, $29^{\circ} 41^{\prime} 03^{\prime \prime} \mathrm{S}$ and $53^{\circ} 48^{\prime} 25^{\prime \prime} \mathrm{W}$. The cultivar used was Eldorado with ten year old plants that were spaced $1.5 \times 5$ $\mathrm{m}$ in a Y-shaped conduction system.

\section{Pre and postharvest control of brown rot}

In the first year (2014), from October to December, the experimental design was a randomized block with four replications, seven treatments and experimental units of six plants. The treatments were the following products (active ingredients): [1] control (4 water applications); [2] captan (4 applications); [3] iprodione (4 applications); [4] iminoctadine (2 applications); [5] tebuconazole (3 applications); [6] difenoconazole (3 applications); [7] azoxystrobin (3 applications). The preharvest applications began 24 days before harvest, following the recommended doses for each active ingredient and adapting them to a spray volume of $1000 \mathrm{~L} \mathrm{ha}^{-1}$ (Table 1).

Previous cultural practices for the implementation of the experiment consisted of fertilization, pest control, pruning and thinning fruit according to the technical recommendations for crop. The controlling of the disease 
began with the removal of mummified fruit during the dormancy period; thereafter chemical treatments were carried out from the flowering stage. The products used

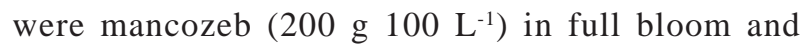

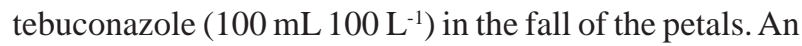

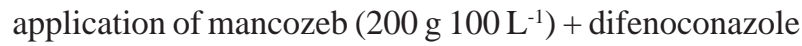
$\left(30 \mathrm{~mL} 100 \mathrm{~L}^{-1}\right)$ was conducted during thinning. After this period, preharvest applications were carried out as the experimental treatments.

In order to evaluate the incidence of the disease in the field, the incidence of brown rot was recorded weekly, taking into account the number of fruit with lesions in relation the total of fruit evaluated. The count was held every week until harvest and the results were expressed as a percentage of brown rot. After harvest, fruit without apparent infection were transported to the laboratory for evaluation of the postharvest incidence. A batch of fruit from each treatment was stored at $-0.5 \pm 0.2{ }^{\circ} \mathrm{C}$, under a relative humidity $(\mathrm{RH})$ of $96 \pm 1 \%$, for 40 days, whereas another batch was stored at $20{ }^{\circ} \mathrm{C}$ in order to assess the incidence of brown rot. In order to evaluate the protective efficiency of the treatment, another batch of fruit was submitted to injuries in the epidermis and then inoculated with fungus Monilinia fructicola. The isolate, the same experimental area, was cultivated on potato dextrose agar (PDA) and later formed a suspension of $10^{5} \mathrm{~mL}^{-1}$ spores with the aid of a Neubauer chamber. Each fruit was drilled in the equatorial region, with the aid of a tip of $3 \mathrm{~mm}$ diameter and $5 \mathrm{~mm}$ in depth, where $30 \mu \mathrm{L}$ spore suspension was inoculated. In fruit uninjured, inoculation was performed in a marked point in the equatorial region. After drying the inoculated aliquot, the fruit were stored and evaluated as aforementioned for the fruit without inoculation.
During harvest and postharvest, disease incidence was evaluated at two and four days of shelf life ( $20 \pm 0.5$ ${ }^{\circ} \mathrm{C}$ ). Four replicates of 20 fruit from each treatment were analyzed for all evaluations. The chamber temperature was controlled by electronic thermostats and monitored daily by a thermometer with mercury bulb, with accuracy of 0.2 ${ }^{\circ} \mathrm{C}$, inserted into the flesh of a fruit and $\mathrm{RH}$ monitored by a psychrometer. When necessary, the atmosphere was humidified in order to maintain $>96 \%$ humidity.

\section{Evaluation of latent infection}

During the second year (2015), from July to December, we evaluated the incidence of latent infections during growth and ripening of fruit and correlated this data with the disease occurrence in postharvest. Samplings were held at the fall of the sepals, during thinning of fruit, 30 days after thinning (DAT), 15 days before harvest (DBH) and during harvest, in two cultivars and from plants that were and weren't submitted to fungicide application. The cultivars used were 'Maciel' and 'Eldorado', dual purpose. The 'Maciel' is characterized by the present yellow flesh, firm, non-fondant with sweet-sour flavor and soluble solids content between 11 and $16{ }^{\circ} \mathrm{Brix}$, with flowering in late July to early August and harvest in the second to third week from December. Cultivar Eldorado delayed, with flowering in late August and harvest in the last days of December. It also has yellow flesh, firm and adherent to the core, with sweet-sour flavor, with 15 to $17{ }^{\circ}$ Brix and acidity quite pronounced. The phytosanitary treatment for disease management was with mancozeb, captan, procymidone, iminoctadine, tebuconazole and iprodione, the former two were applied at flowering and the others were used in alternation, with an application during thinning and four during preharvest. At each sampling

Table 1: Characteristics of fungicides and date of application of fungicides and dates and volumes of rainfall in December in Santiago, RS, Brazil (crop 2014)

\begin{tabular}{|c|c|c|c|c|c|c|c|c|}
\hline \multirow[b]{2}{*}{ Treatments } & \multicolumn{7}{|c|}{ Characteristics of fungicides and dates of applications } & \multirow[b]{2}{*}{$\begin{array}{l}1 \mathrm{DBH} \\
\mathrm{Dec} / 21\end{array}$} \\
\hline & $\begin{array}{l}\text { Mode } \\
\text { of action }\end{array}$ & $\begin{array}{c}\text { Safe range } \\
\text { (Days) }\end{array}$ & Doses & $\begin{array}{c}24 \mathrm{DBH} * \\
\text { Nov/30 }\end{array}$ & $\begin{array}{l}14 \mathrm{DBH} \\
\mathrm{Dec} / 08\end{array}$ & $\begin{array}{l}7 \mathrm{DBH} \\
\text { Dec/15 }\end{array}$ & $\begin{array}{l}3 \text { DBH } \\
\text { Dec/18 }\end{array}$ & \\
\hline Control & - & - & - & $\mathrm{X}^{* *}$ & $X$ & $\mathrm{X}$ & \multirow{7}{*}{$\mathrm{X}$} & \multirow{7}{*}{$\mathrm{X}$} \\
\hline Captan & Contact & 1 & $240{\mathrm{~g} 100 \mathrm{~L}^{-1}}^{-1}$ & $\mathrm{X}$ & $X$ & $X$ & & \\
\hline Iprodione & Contact & 3 & $150 \mathrm{~mL} 100 \mathrm{~L}^{-1}$ & $\mathrm{X}$ & $X$ & \multirow{5}{*}{$\begin{array}{l}X \\
X\end{array}$} & & \\
\hline Iminoctadine & Contact & 14 & $150 \mathrm{~mL} 100 \mathrm{~L}^{-1}$ & $\mathrm{X}$ & $\mathrm{X}$ & & & \\
\hline Tebuconazole & Systemic & 7 & $100 \mathrm{~mL} 100 \mathrm{~L}^{-1}$ & $\mathrm{X}$ & $\mathrm{X}$ & & & \\
\hline Azoxistrobina & Systemic & 7 & 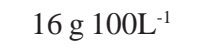 & $\mathrm{X}$ & $\mathrm{X}$ & & & \\
\hline Difenoconazol & Systemic & 10 & $30 \mathrm{ml} 100 \mathrm{~L}^{-1}$ & $\mathrm{X}$ & $\mathrm{X}$ & & & \\
\hline \multicolumn{9}{|c|}{ Harvest: 22 of December } \\
\hline \multicolumn{9}{|c|}{ Dates of rainfall } \\
\hline Date & Dec/1 & Dec/ 4-5 & Dec/7 & Dec/11-12-13 & Dec/16 & \multicolumn{2}{|c|}{ Dec/19-20-21 } & Total \\
\hline Volume (mm) & 7.2 & 22.8 & 26.6 & 97.8 & 8.0 & \multicolumn{2}{|c|}{113.2} & 275.6 \\
\hline
\end{tabular}

*DBH: Days before harvest; ** Date of applications 
date, 80 fruit were randomly selected from eight trees, which were randomly distributed in the orchard, put in paper bags and sent to the laboratory.

\section{Determination of latent infection in green fruit}

The fruit were surface sterilized for one minute in a $70 \%$ ethanol solution, followed by one minute in $0.5 \%$ sodium hypochlorite and then washed three times in sterile water. Unripe fruit were immersed in a paraquat solution $\left(6 \mathrm{~mL} \mathrm{~L}^{-1}\right)$ for 1 minute in order to induce senescence in the tissues and activate latent infections (Northover \& Cerkauskas, 1994). After the treatment, all fruit were placed in a humid chamber inside of plastic receptacles containing moistened filter paper, the temperature was held at $20^{\circ} \mathrm{C}$. The incidence of the disease was evaluated every 48 hours during six days. During this period, the fruit internally infected by the pathogen expressed abundant sporulation, which was clearly distinguishable from other fungal infections.

\section{Determination of latent infection in mature fruit}

In order to detect latent infection in mature fruit (harvest), 80 fruit from each treatment and cultivar were sterilized according to the previous procedure, with the exception of the paraquat application. Another batch of 80 fruit were only sprayed with sterile water and, placed in a humid chamber at a temperature of $20^{\circ} \mathrm{C}$ and evaluated for six days. This procedure was performed in fruit after harvest. Following a batch of fruit was evaluated and another stored for 35 days under refrigeration at $-0.5{ }^{\circ} \mathrm{C}$ and relative humidity $(\mathrm{RH})$ of $96 \pm 1 \%$, to verify the role of latent infection in disease incidence at postharvest.

The parameters evaluated were: a) total brown rot incidence in fruit with no sterilization; b) latent infection: incidence of rot in fruit that had been submitted to superficial sterilization; c) external contamination: determined by the difference between incidence of total decay and latent infections; d) brown rot incidence in field: monitoring the incidence of brown rot until the time of harvest, in all 8 plants used for each treatment (4 replicates of 2 plants). All results were expressed as percentage of fruit with rot.

\section{Statistical analysis}

The data, prior to analysis of variance (ANOVA), were submitted to the errors normality test (Lilliefors) and the parameters that were not normal (evaluation of latent infection, pre and postharvest control of brown rot and determination of latent infection in mature fruit) were transformed by arc.sen $\sqrt{x / 100}$. Means were grouped by the Scott-Knott test at $\mathrm{p}<0.05$, with software Sisvar-version 5.3-UFLA (Ferreira, 2011), and after between the variables the incidence of latent infection Monilinia fructicola on different dates and the incidence disease at harvest and postharvest was used Pearson correlation at $\mathrm{p}<0.05$.

\section{RESULTS AND DISCUSSION}

\section{Performance of fungicides in controlling preharvest brown rot}

The active ingredients difenoconazole, tebuconazole and iprodione showed greater efficiency in the brown rot control in the field in comparison to other products tested, with $90.9 \%, 90.2 \%$ and $90.6 \%$ of control, respectively (Figure 1C). Although rainfall levels were high during the period of application (Figure 1A and B), and the fact that these products are widely used by fruit growers, their efficiency was still assured, being important alternatives for brown rot management of peach culture. High rainfall and relative humidity in the months of development and maturation of fruit (October to December), as observed in the year of the study (Figure 1A), predisposes to increased infections and in this case the intensification of applications is required, and the use of fungicides efficient. This result confirms those obtained by Pavanello et al., (2015) with satisfactory preharvest control of brown rot with difenoconazole, tebuconazole, procymidone, azoxystrobin and trifloxystrobin / tebuconazole. Holb \& Schnabel (2007) found that the triazoles have a high protective activity reinforcing the control of brown rot. This can be observed in Table 1, where the presence of fungi from latent infection is low with tebuconazole. Nevertheless, although the iminoctadine fungicide did not present the best preharvest control, this fungicide resulted in a low incidence of latent infections at harvest, resulting in high control of postharvest brown rot (Table 2).

\section{Performance of fungicides to control of postharvest brown rot}

In postharvest, during exposition of the fruit at $20^{\circ} \mathrm{C}$, the incidence of brown rot showed significant interaction between fungicides and the time of evaluation, at harvest and after storage (Table 2). At harvest, plus two days of shelf at $20^{\circ} \mathrm{C}$, iprodione, iminoctadine, tebuconazole and difenoconazole resulted in no incidence of the disease, while after cold storage iminoctadine was the one who controlled at $100 \%$ brown rot. When comparing the evaluation period, only iminoctadine did not increase the incidence of brown rot after cold storage. After four days of exposure to $20^{\circ} \mathrm{C}$, the iminoctadine fungicide, followed by tebuconazole resulted in the lowest incidence of the disease, both at harvest and after cold storage, with control of $98.1 \%$ and $97 \%$ at harvest, $96.2 \%$ and $73.9 \%$ after storage, respectively. The preharvest iminoctadine application has been found effective in control of postharvest brown rot in the states of Rio Grande do Sul and Paraná (Moreira \& May-De Mio, 2009), even during long periods of fruit storage (Pavanello et al., 2015). 
The effect of fungicides applied during preharvest on fruit that had suffered injuries after harvest can be seen in Table 3. When fungicides were applied, the injuries were found to cause an increase of disease incidence, except for the treatment with Iprodione with $71.3 \%$ control the disease for up to two days at $20^{\circ} \mathrm{C}$. At four days at $20^{\circ} \mathrm{C}$, the lowest incidence was found with the application of iminoctadine fungicide in injured fruit $(52.9 \%$ of control), while iminoctadine and tebuconazole controlled $94.7 \%$ and $89.6 \%$ respectively in the fruit without injury. After cold storage, besides the iprodione fungicide, captan also delayed the incidence of decay up to two days at $20{ }^{\circ} \mathrm{C}$, however after four days the incidence in injured fruit was higher for all treatments. During this period, in fruit without injuries, iminoctadine fungicide resulted in same behavior at the time of harvest, with 94.5\% disease control (Table 3).

At harvest, the prevention of mechanical damage and immediate cold storage constitute the most effective decay prevention measures. Martins et al., (2005) showed correlation between the frequency of fruit mechanical damage and decay incidence. Thus, the use of fungicides that can delay decay incidence by injury in the epidermis is an important strategy for reducing the inoculum in postharvest, reducing losses.

\section{Relationship of latent infection with postharvest brown rot}

The incidence of latent infection in fruit the cultivar Eldorado was diagnosed in all samples, while in fruit of cultivar Maciel latent infection appeared from the thinning until harvest, as shown in Table 4. Regarding the magnitude of symptoms, we observed that the closer the harvest, the greater the manifestation of latent infection. Several authors reported that closeness of fruit ripening favors the expression of latent infections, which can also occur during postharvest or senescence (Luo et al., 2001; Mari et al., 2003; Luo \& Michailides, 2003; Villarino et al., 2012). In this study, the infection was probably facilitated by environmental conditions favorable to disease, such as high temperature $\left(+/-20^{\circ} \mathrm{C}\right)$ and high relative humidity, observed mainly in the months from October to December, that are the dates of collection after thinning, 15 days before harvest and harvest of this study (Figure 2). In addition, the high concentration of inoculum in the area due to the early ripening cultivars (Granada, Eldorado and Maciel) in the experimental area, can also explain the high incidence of latent infections in the 'Eldorado', which maturation occurred in mid-December. The potential inoculum, humidity and temperature are critical factors in disease prediction (Luo \& Michailides 2001, Bannon et

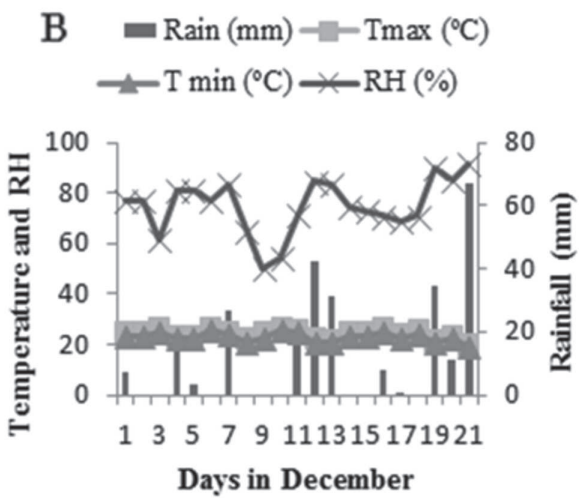

C

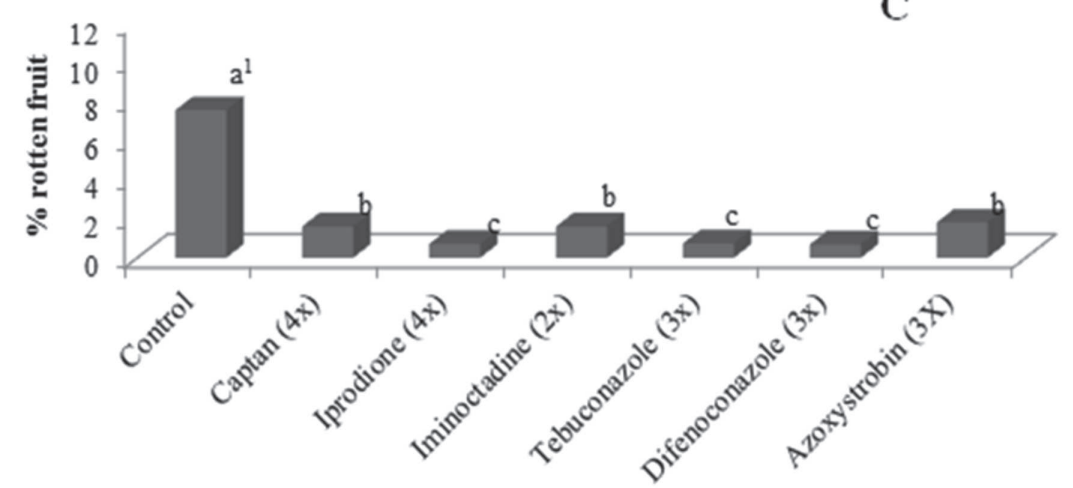

Figure 1: Rainfall, relative humidity (RH) and temperature recorded at the weather station in Santiago, RS (A and B) (Crop 2014). Incidence of brown rot at harvest, after treatments preharvest with fungicides in peaches cv. Eldorado (C). 1 Means followed by equal letters belong to the same group by Scott-Knott test $(\mathrm{p}<0.05)$. 
al., 2009, Gell et al., 2008). In order for latent infections to develop, wetness needs to be maintained for longer than 22 hours when temperature is $8^{\circ} \mathrm{C}$ or for 5 hours when temperature is $25^{\circ} \mathrm{C}$ (Gell et al., 2008).

The low incidence of latent infections in fruit treated with fungicides is probably due to the efficiency of products used in disease control, acting as preventives and curatives, reducing the onset of symptoms, including postharvest period (Table 4). The use of appropriate protective fungicides can protect the fruit, reduce sporulation and inoculum survival supplies (Ogawa et al., 1995). The incidence of latent infections were virtually not found in the cultivar Maciel, which was treated with fungicides, In cultivar Eldorado the manifestation occurred at the beginning of fruit growth and at harvest, which coincides with the period of greatest rainfall and relative humidity (September, October and December of 2014) and that probably reduce the efficiency of applied products (Figure 2). Factors that predispose the incidence of latent infections such as temperature, humidity and high concentration of inoculum, associated with favorable growth stages of the disease, may have influenced the control strategies. Susceptibility to brown rot infection is dependent on the developmental stage of the fruit (Gell et al., 2008). The immature fruit during the pit hardening stage are more resistant to infection by Monilinia spp. than mature fruit (Lee \& Bostock, 2007; Xu et al., 2007; Gell et al., 2008).

At harvest, both latent infection and the infection from surface spores were found to have the same weight on the epidemic of the disease, regardless of the use of fungicides, and this significantly reduced the incidence of rot, regardless of the cultivar (Table 4). After cold storage, the results also showed no interaction between the causes of brown rot (external contamination and latent infection) with the use of fungicides, where there is greater incidence of brown rot from the latent infection and without the application of fungicides. A reduction of chemical and mechanical resistance to the development of the pathogen is noticed with the advance of maturation and especially after cold storage. With maturation, physiological and biochemical responses in the host can trigger changes and activate the pathogen, which would leave its phase of low metabolic rate (quiescent) and would stimulate pathogenicity factors, resulting in an active parasite development (Prusky, 1996; Fischer et al., 2010). The greater sensitivity of fruit maturation can also be related to $\mathrm{pH}$ and content of soluble solids, since total soluble solids include reducing sugars and other molecules readily consumed by fungi (Walker \& White, 2005). The

Table 2: Effect of fungicides on the incidence of latent infection by $M$. fructicola in mature fruit, for six days at $20^{\circ} \mathrm{C}$ and postharvest brow rot incidence after harvest and 40 days of cold storage (CS) to $-0.5^{\circ} \mathrm{C}$, four days at $20^{\circ} \mathrm{C}$. Santa Maria, RS, Brasil (crop 2014)

\begin{tabular}{|c|c|c|c|c|}
\hline \multirow{2}{*}{ Preharvest treatments } & \multicolumn{4}{|c|}{ Rot caused by latent infection (\%) } \\
\hline & \multicolumn{2}{|r|}{2 days } & \multicolumn{2}{|r|}{6 days } \\
\hline Control & \multicolumn{2}{|r|}{$20.8 \mathrm{a}$} & \multicolumn{2}{|r|}{$87.5 \mathrm{a}$} \\
\hline Captan $(4 \mathrm{x})$ & \multicolumn{2}{|r|}{$3.75 \mathrm{c}$} & \multicolumn{2}{|r|}{$42.0 \mathrm{~d}$} \\
\hline Iprodione $(3 \mathrm{x})$ & \multicolumn{2}{|r|}{$8.75 b$} & \multicolumn{2}{|r|}{$75.0 \mathrm{~b}$} \\
\hline Iminoctadine $(2 \mathrm{x})$ & \multicolumn{2}{|r|}{$0.00 \mathrm{~d}$} & \multicolumn{2}{|r|}{$5.00 \mathrm{f}$} \\
\hline Tebuconazole $(3 \mathrm{x})$ & \multicolumn{2}{|r|}{$3.52 \mathrm{c}$} & \multicolumn{2}{|r|}{$26.9 \mathrm{e}$} \\
\hline Difenoconazole $(2 \mathrm{x})$ & \multicolumn{2}{|r|}{$7.82 \mathrm{~b}$} & \multicolumn{2}{|r|}{$60.2 \mathrm{c}$} \\
\hline Azoxystrobin $(3 \mathrm{x})$ & \multicolumn{2}{|r|}{$6.25 b$} & \multicolumn{2}{|r|}{$54.3 \mathrm{c}$} \\
\hline$\overline{\mathrm{CV}(\%)}$ & \multicolumn{2}{|r|}{15.2} & \multicolumn{2}{|r|}{9.04} \\
\hline \multirow[t]{3}{*}{ Preharvest treatments } & \multicolumn{4}{|c|}{ Postharvest brown rot incidence (\%) } \\
\hline & \multicolumn{2}{|c|}{2 days at $20^{\circ} \mathrm{C}$} & \multicolumn{2}{|c|}{4 days at $20^{\circ} \mathrm{C}$} \\
\hline & After harvest & AfterCS & After harvest & After CS \\
\hline Control & $20.0 \mathrm{aB}^{(1)}$ & $51.2 \mathrm{aA}$ & $68.7 \mathrm{aB}$ & $86.2 \mathrm{aA}$ \\
\hline Captan $\left(4 x^{(2)}\right)$ & $7.38 \mathrm{bB}$ & $11.2 \mathrm{cA}$ & $21.0 \mathrm{bB}$ & $42.5 \mathrm{cA}$ \\
\hline Iprodione $(4 \mathrm{x})$ & $0.00 \mathrm{~dB}$ & $11.2 \mathrm{cA}$ & $14.7 \mathrm{bB}$ & $46.2 \mathrm{bA}$ \\
\hline Iminoctadine $(2 \mathrm{x})$ & $0.00 \mathrm{dA}$ & $0.00 \mathrm{dA}$ & $3.75 \mathrm{eA}$ & $3.25 \mathrm{eA}$ \\
\hline Tebuconazole $(3 \mathrm{x})$ & $0.00 \mathrm{~dB}$ & $12.5 \mathrm{cA}$ & $6.25 \mathrm{~dB}$ & $22.5 \mathrm{dA}$ \\
\hline Difenoconazole $(3 \mathrm{x})$ & $0.00 \mathrm{~dB}$ & $10.1 \mathrm{cA}$ & $12.5 \mathrm{cB}$ & $38.6 \mathrm{cA}$ \\
\hline Azoxystrobin $(3 x)$ & $3.75 \mathrm{cB}$ & $16.2 \mathrm{bA}$ & $21.2 \mathrm{bB}$ & $51.2 \mathrm{bA}$ \\
\hline Mean & 4.44 & 16.0 & 21.1 & 41.5 \\
\hline
\end{tabular}

${ }^{1}$ Means followed by equal letters, lowercase in the columns and uppercase in the lines, belong to the same group by Scott Knott test (p < 0.05). ${ }^{2}$ Number of preharvest applications

Rev. Ceres, Viçosa, v. 65, n.6, p. 517-526, nov/dez, 2018 
fungus Monilinia fructicola is known for having the ability to infect green fruit and manifesting itself mainly after storage, this fact reinforces the importance of appropriate chemical treatment in the field, aiming to protect the flowers and fruit, both in the initial stage of development as during harvest.
Monitoring latent infection allows us to correlate the postharvest disease occurrence with different collection periods during fruit development. We observed that the closer the harvest, the greater the correlation between the incidence of latent infection to the manifestation of the disease in postharvest, both right after harvest as well as

Table 3: Fungicidal effect of products applied in the field of 'Eldorado' peaches in control of brown rot in injured fruit at harvest. Santa Maria, RS, Brazil (crop 2014)

\begin{tabular}{|c|c|c|c|c|}
\hline \multirow{4}{*}{ Preharvest treatments } & \multicolumn{4}{|c|}{ Brown rot incidence (\%) } \\
\hline & \multicolumn{4}{|c|}{ After harvest } \\
\hline & \multicolumn{2}{|c|}{2 days at $20^{\circ} \mathrm{C}$} & \multicolumn{2}{|c|}{4 days at $20^{\circ} \mathrm{C}$} \\
\hline & With injury & No injury & With injury & No injury \\
\hline Control & $26.2 \mathrm{aA}^{(1)}$ & $26.7 \mathrm{aA}$ & $87.5 \mathrm{aA}$ & $71.2 \mathrm{aB}$ \\
\hline $\operatorname{Captan}\left(4 \mathrm{x}^{(2)}\right)$ & $18.0 \mathrm{bA}$ & $1.25 \mathrm{cB}$ & $89.6 \mathrm{aA}$ & $20.0 \mathrm{cB}$ \\
\hline Iprodione $(3 \mathrm{x})$ & $7.50 \mathrm{dA}$ & $6.25 \mathrm{bA}$ & $65.0 \mathrm{cA}$ & $36.5 \mathrm{bB}$ \\
\hline Iminoctadine $(2 \mathrm{x})$ & $15.0 \mathrm{cA}$ & $1.25 \mathrm{cB}$ & $41.2 \mathrm{eA}$ & $3.75 \mathrm{~dB}$ \\
\hline Tebuconazole $(3 \mathrm{x})$ & $12.5 \mathrm{cA}$ & $1.25 \mathrm{cB}$ & $52.5 \mathrm{dA}$ & $7.38 \mathrm{~dB}$ \\
\hline Difenoconazole $(2 \mathrm{x})$ & $13.0 \mathrm{cA}$ & $2.50 \mathrm{cB}$ & $62.4 \mathrm{cA}$ & $23.8 \mathrm{cB}$ \\
\hline Azoxystrobin $(3 \mathrm{x})$ & $8.98 \mathrm{dA}$ & $3.81 \mathrm{bB}$ & $77.9 \mathrm{bA}$ & $25.4 \mathrm{cB}$ \\
\hline Mean & 14.5 & 6.14 & 68.3 & 26.9 \\
\hline \multirow[t]{2}{*}{$\mathrm{CV}(\%)$} & \multicolumn{2}{|c|}{34.6} & \multicolumn{2}{|c|}{9.28} \\
\hline & \multicolumn{4}{|c|}{ After 40 days cold storage } \\
\hline \multirow[t]{2}{*}{ Preharvest treatments } & \multicolumn{2}{|c|}{2 days at $20^{\circ} \mathrm{C}$} & \multicolumn{2}{|c|}{4 days at $20^{\circ} \mathrm{C}$} \\
\hline & With injury & No injury & With injury & No injury \\
\hline Control & $36.2 \mathrm{aA}$ & $35.9 \mathrm{aA}$ & $100.0 \mathrm{aA}$ & $91.0 \mathrm{aB}$ \\
\hline Captan $(4 x)$ & $5.00 \mathrm{cB}$ & $10.0 \mathrm{bA}$ & $97.4 \mathrm{aA}$ & $33.7 \mathrm{bB}$ \\
\hline Iprodione $(3 \mathrm{x})$ & $2.50 \mathrm{cB}$ & $7.50 \mathrm{bA}$ & $77.5 \mathrm{cA}$ & $47.5 \mathrm{bB}$ \\
\hline Iminoctadine $(2 \mathrm{x})$ & $0.00 \mathrm{dA}$ & $0.00 \mathrm{cA}$ & $33.7 \mathrm{dA}$ & $5.00 \mathrm{~dB}$ \\
\hline Tebuconazole $(3 \mathrm{x})$ & $7.50 \mathrm{bA}$ & $0.00 \mathrm{cB}$ & $70.0 \mathrm{cA}$ & $21.6 \mathrm{cB}$ \\
\hline Difenoconazole $(2 \mathrm{x})$ & $10.3 \mathrm{bA}$ & $3.75 \mathrm{bB}$ & $79.7 \mathrm{cA}$ & $35.0 \mathrm{bB}$ \\
\hline Azoxystrobin $(3 \mathrm{x})$ & $5.00 \mathrm{bA}$ & $4.88 \mathrm{bA}$ & $91.2 \mathrm{bA}$ & $38.3 \mathrm{bB}$ \\
\hline Mean & 6.30 & 8.87 & 78.5 & 38.8 \\
\hline $\mathrm{CV}(\%)$ & \multicolumn{2}{|c|}{35.5} & \multicolumn{2}{|c|}{9.41} \\
\hline
\end{tabular}

${ }^{1}$ Means followed by equal letters, lowercase in the columns and uppercase in the lines, belong to the same group by Scott Knott test (p < $0.05) .{ }^{2}$ Number of preharvest applications.

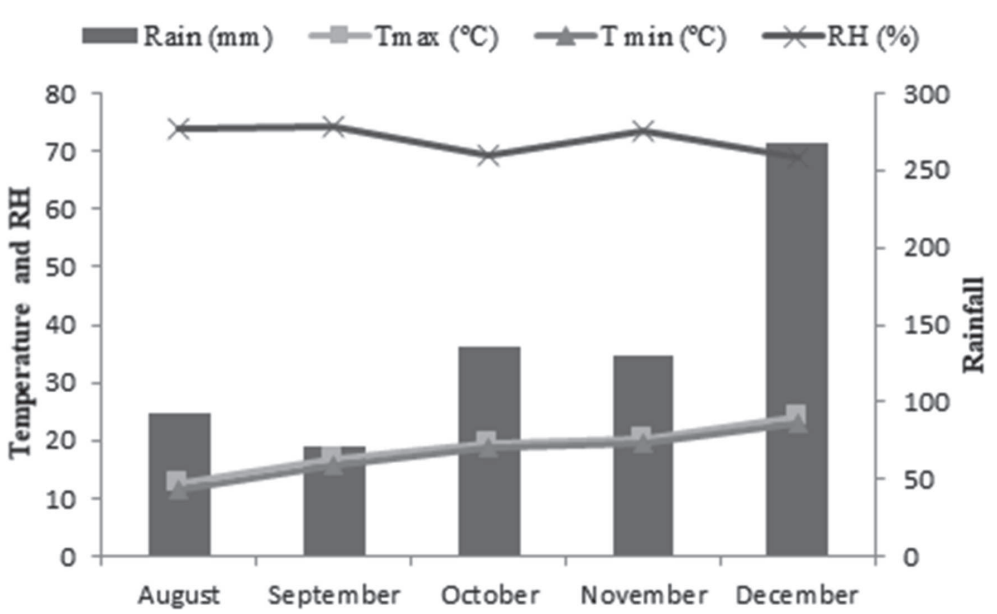

Figure 2: Rainfall, relative humidity (RH) and temperature, recorded at the weather station in Santiago, RS, Brazil (crop 2015). 


\begin{tabular}{|c|c|c|c|c|c|c|c|c|c|}
\hline \multirow[b]{2}{*}{ Treatments } & & \multicolumn{3}{|c|}{ Latent infections(\%) } & \multicolumn{5}{|c|}{ Brown rot incidence $(\%)$} \\
\hline & & $\begin{array}{l}\text { Sepals } \\
\text { falling }\end{array}$ & Thinning & 30 DAT $^{(4)}$ & $15 \mathrm{DBH}^{(5)}$ & Harvest & $\begin{array}{c}\text { Rot } \\
\text { Field }^{(6)}\end{array}$ & $\begin{array}{l}\text { 7days } \\
20^{\circ} \mathrm{C}\end{array}$ & $\begin{array}{c}\mathrm{CS}+7 \\
\text { days } 20^{\circ} \mathrm{C}\end{array}$ \\
\hline \multirow{2}{*}{ Maciel } & -fung..$^{(2)}$ & 0.00 & 4.00 & 8.00 & 27.5 & 42.0 & 14.4 & 84.4 & 88.9 \\
\hline & + fung. ${ }^{(3)}$ & 0.00 & 1.00 & 0.00 & 0.00 & 0.00 & 1.07 & 2.22 & 31.1 \\
\hline \multirow{2}{*}{ Eldorado } & -fung. & 4.00 & 5.00 & 2.50 & 10.0 & 46.6 & 15.7 & 82.2 & 100.0 \\
\hline & + fung. & 2.00 & 2.50 & 0.00 & 0.00 & 11.1 & 4.06 & 20.0 & 55.6 \\
\hline \multicolumn{10}{|c|}{ Role of latent infection and external contamination postharvest rot } \\
\hline & & \multicolumn{4}{|c|}{ Causes brown rot at harvest } & \multicolumn{4}{|c|}{ Causes of brown rot after $\mathbf{4 0}$ days of storage } \\
\hline & & $\begin{array}{l}\text { Total rot } \\
\text { infection }\end{array}$ & $\begin{array}{c}\text { Latent } \\
\text { contamination }\end{array}$ & External & Mean & Total rot & $\begin{array}{c}\text { Latent } \\
\text { infection }\end{array}$ & $\begin{array}{c}\text { External } \\
\text { contamination }\end{array}$ & Mean \\
\hline \multirow{4}{*}{ Maciel } & - fung. & $84.4 \mathrm{a}^{(1)}$ & 42.0 & 42.2 & $42.1 \mathrm{a}$ & $88.9 \mathrm{a}$ & 53.3 & 35.6 & $44.4 \mathrm{a}$ \\
\hline & + fung. & $2.22 \mathrm{~b}$ & 0.00 & 2.22 & $1.11 \mathrm{~b}$ & $31.1 \mathrm{~b}$ & 28.8 & 2.30 & $15.5 \mathrm{~b}$ \\
\hline & Mean & & $21.0 \mathrm{~A}$ & $22.2 \mathrm{~A}$ & & & $41.1 \mathrm{~A}$ & $22.2 \mathrm{~B}$ & \\
\hline & $\mathrm{CV}(\%)$ & 17.9 & \multicolumn{2}{|c|}{14.9} & & 10.1 & \multicolumn{2}{|c|}{4.21} & \\
\hline \multirow{4}{*}{ Eldorado } & -fung. & $82.2 \mathrm{a}$ & 46.6 & 35.6 & $41.1 \mathrm{a}$ & 100.0 & 57.7 & 42.3 & $50.0 \mathrm{a}$ \\
\hline & + fung. & $20.0 \mathrm{~b}$ & 11.1 & 8.90 & $10.0 \mathrm{~b}$ & 55.5 & 40.0 & 15.5 & $27.7 \mathrm{~b}$ \\
\hline & Mean & & $28.8 \mathrm{~A}$ & $22.2 \mathrm{~A}$ & & & $48.8 \mathrm{~A}$ & $28.9 \mathrm{~B}$ & \\
\hline & $\mathrm{CV}(\%)$ & 17.7 & \multicolumn{2}{|c|}{26.3} & & 16.6 & \multicolumn{2}{|c|}{7.91} & \\
\hline
\end{tabular}

${ }^{1}$ Means followed by equal letters belong to the same group by Scott Knott test $(\mathrm{p}<0.05)^{2}$ - fung.: Fruit not treated with fungicides. ${ }^{3}+$ fung.: fruit treated with fungicide. ${ }^{4}$ DAT: Days after thinning. ${ }^{5}$ DBH:

Days before harvest. ${ }^{6}$ Cumulative rot values field to harvest. 
Table 5: Pearson correlation between the incidence of latent infection Monilinia fructicola on different dates and the disease incidence at harvest and postharvest

\begin{tabular}{|c|c|c|c|c|c|c|c|}
\hline $\begin{array}{l}\text { Correlation } \\
\text { Pearson }\end{array}$ & $\begin{array}{l}\text { Sepals } \\
\text { Falling }\end{array}$ & Thinning & $30 \mathrm{DAT}^{(2)}$ & $15 \mathrm{DBH}^{(3)}$ & Harvest & Postharvest & $\begin{array}{c}\text { After } 35 \\
\text { days } \mathrm{CS}^{(4)}\end{array}$ \\
\hline Sepals Falling & 1 & & & & & & \\
\hline Thinning & $n s^{(1)}$ & 1 & & & & & \\
\hline 30 DAT & $n s$ & $n s$ & 1 & & & & \\
\hline $15 \mathrm{DBH}$ & $n s$ & $n s$ & 0.96 & 1 & & & \\
\hline Harvest & $n s$ & 0.51 & 0.66 & 0.74 & 1 & & \\
\hline Postharvest & $n s$ & 0.48 & 0.68 & 0.78 & 0.94 & 1 & \\
\hline After 35 days CS & 0.48 & $n s$ & 0.52 & 0.61 & 0.91 & 0.95 & 1 \\
\hline
\end{tabular}

${ }^{1}$ No significant correlation ( $>$ 0.05). ${ }^{2}$ DAT: Days after thinning. ${ }^{3} \mathrm{DBH}$ : Days before harvest. ${ }^{4} \mathrm{CS}$ : cold storage.

after cold storage (Table 5). According to Emery et al., (2000), although the detection of latent infections during the fruit's ripening period is important for the understanding of likely brown rot epidemics, it does not provide information in sufficient time to control the disease during preharvest. However, in this study, there was a significant correlation between the incidence of latent infection in immature fruit and the incidence of postharvest rot, confirming results obtained for Luo \& Michailides (2001) \& Xu et al., (2007). This reinforces the importance of management strategies throughout the growth phase of fruit for disease control in the postharvest, especially after cold storage. Latent infection plays an important role in postharvest disease incidence, which may correspond to more than $50 \%$ of brown rot (Table 4 ).

\section{CONCLUSIONS}

Applications in the field of iprodione, tebuconazole and difenoconazole are efficient in the preharvest brown rot control, while the iminoctadine has efficacy in the disease control in postharvest, as well as acting on latent infections.

Wounds on the skin of the fruit increase the incidence of the fungus Monilinia fructicola, however preharvest iprodione application delays the disease.

The incidence of latent infections of the fruit has a positive correlation with postharvest brown rot, reinforcing the need for proper control of the disease during the preharvest in order to extend the postharvest life of fruit.

After cold storage, the highest incidence of brown rot is due to the manifestation of latent infections.

\section{ACKNOWLEDGEMENTS}

To Conselho Nacional de Desenvolvimento Científico e Tecnológico (CNPq) and Coordenação de Aperfeiçoamento de Pessoal de Nível Superior (CAPES), for financial support.

\section{REFERENCES}

Bannon F, Gort G, Leeuwen G, Holb I \& Jeger M (2009) Diurnal patterns in dispersal of Monilinia fructigena conidia in an apple orchard in relation to weather factors. Agricultural and Forest Meteorology, 149:518-525.

Burnett AL, Lalancette N \& Mcfarland KA (2010) Effect of QoI fungicides on colonization and sporulation of Monilinia fructicola on peach fruit and blossom blight cankers. Plant Diseases, 94:1000-1008.

Casals C, Elmer PAG, Viñas I, Teixidó N, Sisquella M \& Usall J (2012) The combination of curing with either chitosan or Bacillus subtilis CPA-8 to control brown rot infections caused by Monilinia fructicola. Postharvest Biology Technology, 64:126-132.

Emery KM, Michailides TJ \& Scherm H (2000) Incidence of latent infection of immature peach fruit by Monilinia fructicola and relationship to brown rot in Georgia. Plant Disease, 84:853857.

Ferreira DF (2011) Sisvar: a computer statistical analysis system. Ciência e Agrotecnologia, 35:1039-1042.

Fischer IH, Arruda MC, Almeida AM \& Montes SMNM (2010) Doenças e características físico-químicas pós-colheita em pêssego 'Régis' produzido em Presidente Prudente-SP. Semina: Ciências Agrárias, 31:627-632.

Gell I, De Cal A, Torres R, Usall J \& Melgarejo P (2008) Relationship between the incidence of latent infections caused by Monilinia spp. and the incidence of brown rot of peach fruit: factors affecting latent infection. European Journal of Plant Pathology, 121:487-498.

Holb IJ \& Schnabel G (2007) Differential effect of triazoles on mycelial growth and disease measurements of Monilinia fructicola isolates with reduced sensitivity to DMI fungicides. Crop Protection, 26:753-759.

Larena I, Torres R, De Cal A, Liñán M, Melgarejoa P, Domenichini P, Bellini A, Mandrin JF, Lichou J, Ochoa de Eribe X \& Usall J (2005) Biological control of postharvest brown rot Monilinia spp.) of peaches by field applications of Epicoccum nigrum. Biological Control, 32:305-310.

Lee MH \& Bostock RM (2007) Fruit exocarp phenols in relation to quiescence and development of Monilinia fructicola infections in Prunus spp.: a role forcellular redox? Phytopathology, 97:269-277.

Luo Y, Ma Z \& Michailides TJ (2001) Analysis of factors affecting latent infection and sporulation of Monilinia fructicola on prune fruit. Plant Disease, 85:999-1003. 
Luo Y \& Michailides TJ (2001) Factors affecting latent infection of prune fruit by Monilinia fructicola. Phytopathology, 91:864872

Luo Y \& Michailides TJ (2003) Threshold conditions that lead latent infection to prune fruit rot caused by Monilinia fructicola. Phytopathology, 93:102-111.

Mari M, Casalini L, Baraldi E, Bertolini P \& Pratella GC (2003) Susceptibility of apricot and peach fruit to Monilinia laxa during phonological stages. Postharvest Biology and Technology, 30:105-109.

Martins MC, Lourenço AS, Gutierrez ASD, Jacomino AP \& Amorim L (2005) Quantificação de danos pós-colheita em pêssegos no mercado atacadista de São Paulo. Fitopatologia Brasileira, 30:587-592.

May-De Mio LL, Moreira LM, Monteiro LB \& Justiniano Júnior JR (2008) Infecção de Monilinia fructicola no período de floração e incidência de podridão parda em frutos de pessegueiro em dois sistemas de produção. Tropical Plant Pathology, $33: 227-234$.

Moreira LM \& May-De Mio LM (2009) Controle da podridão parda do pessegueiro com fungicidas e fosfitos avaliados em pré e pós-colheita. Ciência e Agrotecnologia, 33:405-411.

Northover J \& Cerkauskas RF (1994) Detection and significance of symptom less latent infections of Monilinia fructicola in plums. Jounal Plant Pathology, 16:30-36.

Ogawa JM, Zehr EI, Biggs AR, Bird GW, Ritchie DF, Uriu K \& Uyemoto JK (1995) Compendium of stone fruits diseases. Saint Paul, American Phytopathological Society. 88p.
Pavanello EP, Brackmann A, Thewes FR, Both V, Dos Santos JRA \& Schorr MRW (2015) Eficiência de fungicidas no controle da podridão parda do pessegueiro e sua relação com parâmetros fisiológicos dos frutos. Semina: Ciências Agrárias, 36:67-76.

Prusky D (1996) Pathogen quiescence in postharvest diseases. Annual Review of Phytopathology, 34:13-34.

Sestari I, Giehl RFR, Pinto JAV \& Brackmann A (2008) Condições de atmosfera controlada para pêssegos "Maciel" colhidos em dois estádios de maturação. Ciência Rural, 38:1240-1245.

Villarino M, Melgarejo P, Usall J, Segarra J, Lamarca N \& De Cal (2012) A Secondary inoculum dynamics of Monilinia spp. and relationship to the incidence of postharvest brown rot in peaches and the weather conditions during the growing season. European Journal of Plant Pathology, 133:585-598.

Villarino M, Sandín-España P, Melgarejo P \& De Cal A (2011) High Chlorogenic and Neochlorogenic Acid Levels in Immature Peach Reduce Monilinia laxa Infection by Interfering with Fungal Melanin Biosynthesis. Journal of Agricultural and Food Chemistry, 59:3205-3213.

Walker GM \& White NA (2005) Introduction to Fungal Physiology. In: Kavanagh K (Ed.) Fungi: Biology and Applications. Chichester, John Wiley \& Sons Ltd. p.01-35.

Xu X-M, Bertone C \& Berrie A (2007) Effects of wounding, fruit age and wetness duration on the development of cherry brown rot in the UK. Plant Pathology, 56:114-119. 